\title{
Effect of mineral and organic fertilization on alfalfa forage and soil fertility
}

\author{
Viliana Vasileva', Ognyan Kostov ${ }^{2}$ \\ ${ }^{1}$ Institute of Forage Crops, 89 "General Vladimir Vazov" Str., Pleven 5800, Bulgaria, ${ }^{2}$ Nexus Technology Consultancy Sdn. Bhd., Kompleks \\ Sentral, Unit 2026 and 2027, 2nd Floor, Block C, 33, Jalan Segambut Atas, 51200, Kuala Lumpur, Malaysia
}

\section{A B S TR A C T}

\begin{abstract}
The effect of low and high doses of mineral and organic fertilization on the quality of top yield and root mass of alfalfa and effect of mineral and organic fertilization on formation of quality of soil organic matter in dry condition were studied in a field trial. Alfalfa was grown on leached chernozem soil without irrigation at the experimental field of Institute of Forage Crops, Pleven, Bulgaria. The doses of 70,140 and $210 \mathrm{~kg} / \mathrm{ha}$ mineral nitrogen (active ingredient) were tested as ammonium nitrate and well-rotted cattle manure. It was found dry mass yield of alfalfa fertilized with manure was to $15.9 \%$ higher as compared to dry mass yield obtained from alfalfa fertilized with mineral fertilizer. Sustainable yield index showed the alfalfa crop was more stable under organic fertilization. Alfalfa accumulated to $6027 \mathrm{~kg} / \mathrm{ha}$ dry root mass for 4-year period of growing. There was from 614 to $1371 \mathrm{~kg} / \mathrm{ha}$ root mass additional with manure application. Manure treated plants showed higher values for nitrogen in dry root mass/nitrogen in dry aboveground mass ratio and plant available nitrogen. In addition to nitrogen alfalfa add a considerable amount of organic matter to the soil. Humic acids content after mineral fertilization increased to $50.0 \%$ as compared to unfertilized control and threefold after manure. Humus content in the soil after manure fertilization was from 10.9 to $41.9 \%$ higher as compared to humus content after mineral one.
\end{abstract}

Keywords: Alfalfa; Dry root mass; Manure; Mineral fertilization; Soil fertility

\section{INTRODUCTION}

The conservation of soil fertility issue is highly important nowadays and in the future agricultural research. More effective use of sources for improving the soil fertility, enhancing organic matter, as well as recovering the nutrients have been encouraged (Kusvuran et al., 2014).

The development of methods for healthy and productive soil that provides essential nutrients for plant growth, supports diverse and active soil biotic communities and balances the entire farm ecosystem is one of the core philosophies of eco-organic production systems (Goss et al., 2013).

Legumes contribute to sustainability of the agriculture for many reasons: reduce mineral fertilizers thus reducing $\mathrm{N}_{2} \mathrm{O}$ production and increase $\mathrm{N}_{2}$-fixation, renew and enrich the soil fertility due to their deep reaching root systems, quick decompose their root biomass and accumulate in to the soil (Luscher et al., 2014; Kusvuran et al., 2014). They have become very popular in sustainable cropping practices, as fix atmospheric nitrogen, which can be transferred to a subsequent crop through mineralization of the residues (Luscher et al., 2014). Nitrogen from the biological nitrogen fixation is a major source of nitrogen which is used directly by the plants. Many of legumes could get from 50 to $80 \%$ of their nitrogen needs through biological nitrogen fixation. Therefore the need from nitrogen fertilizers decreased and improves nitrogen nutrition of the plants in an environmentally friendly aspect (Pachev et al., 2009).

Legumes contributed also to the associated grass component in mixtures to be supplied with nitrogen (Luscher et al., 2014). A transfer of part of nitrogen from legume to grass component is performed in grass-legume swards. The amount of transferred nitrogen mainly by decomposition of legume roots and nodules is about 3 to $102 \mathrm{~kg} \mathrm{~N} /$ ha per year, or from 2 to $26 \%$ from biological nitrogen fixation (Ledgard, 1991). Alfalfa, birdsfoot trefoil and red clover provided $80-140 \mathrm{~kg} / \mathrm{ha}$ for associated grass components. Mown and cut biomass and left on the

\footnotetext{
${ }^{*}$ Corresponding author:

Viliana Vasileva, Institute of Forage Crops, “General Vladimir Vazov” Str. 89, Pleven 5800, Bulgaria. E-mail: viliana.vasileva@gmail.com
} 
soil during the fallow period after grass-legume mixture provided $80-160 \mathrm{~N} / \mathrm{h}$ a available nitrogen for the next crop, and after pure legumes 160-260 N/ha. Russelle et al. (2001) found leaching lower losses under pastures with alfalfagrass mixture than a white clover-grass mixture.

The development of sustainable agriculture and conservation of agro ecosystems is the main vision of the national strategies in many countries. It involves the skillful application of science-based approach and innovation and changes in agricultural practices. The present shortages of food supply in many countries required more efforts on this matter.

In Bulgaria 100 million tons of fertile soil is lost annually. Each year 2.5 million tons humus, 4 million tons nitrogen and 3.5 million tons phosphorus disappeared from the soil as well (Bulgarian National Strategy, MAF, 2013).

Alfalfa (Medicago sativa L.) has long time ago been recognized and valued as "soil building" legume crop. This crop has the ability to accumulate significantly more nitrogen than other legumes through its deep rooting system and fix atmospheric $\mathrm{N}_{2}$ from 40 to $80 \%$ of total plant nitrogen through biological nitrogen fixation (Jarvis, 2005). Biederbec et al. (2005) found alfalfa assimilate up to $80 \%$ of plant $\mathrm{N}$ from atmosphere and fixed $299.3 \mathrm{~kg} / \mathrm{ha} \mathrm{N}$ symbiotically. Their roots reached to $50 \mathrm{~m}$ depth and it is considered as the most resistant and resilience crop to the drought (https://www.cotswoldseeds.com/seedinfo/lucerne-practical-guide). It is much more effective in improving soil quality not only because of their large and deep root system, but of the longer growth period and greater capacity for nitrogen fixation, and requires little or no nitrogen fertilizer. In alfalfa-grass stands, nitrogen fertilizer is not needed since alfalfa makes up at least $25 \%$ of the stand. Grass roots intermingle with the alfalfa roots and can use the nitrogen that is released from alfalfa roots and nodules.

Alfalfa, with its deep roots and high water consumption can effectively use excess water (Biederbec et al., 2005). Using alfalfa in mixtures with grasses or use within crop rotation will not only enrich the soil in terms of organic matter, but will also help in physical and chemical fortification of the soil (Kusvuran et al., 2014). Penetration of alfalfa roots will improve also the internal soil drainage and improve soil aeration, thus improve both, symbiotically nitrogen fixation and activity of free living nitrogen fixers in soil. Biederbec et al. (2005) found the increased wheat yield during the later years mainly due to physical subsoil improvements from the deep-rooted alfalfa.

Alfalfa was widely planted in different areas and over 32 million hectares in the world because of its forage, nutritive and high biomass producing values (Veronesi et al., 2010; Xie et al., 2013). The major alfalfa producing regions are North America with 11.9 million ha (41\%), Europe with 7.12 million ha (25\%), South America with 7 million ha (23\%), Asia 2.23 million ha (8\%), Africa $(2 \%)$ and Oceania (1\%) (Yuegao and Cash, 2009). It is the third most valuable crop in the US worth of $\$ 8$ billion per annum (Monteros and Bouton, 2009).

Alfalfa is one of the most important forage legume species in Bulgaria and considered as the crop with the greatest contribution to achievement of sustainable agriculture (Kertikova, 2008). This crop is important for the formation of a higher fertility of the soil on which is grown. This occurs because every time when plants are cut a corresponding amount of the root system dies back and thus providing soil with organic matter that can be immediately degraded by soil micro organisms. As the plants recover from being cut they regrow and roots forage went deeper.

With each successive cut more humus is created. The addition of organic materials of various origins to soil has been one of the most common practices to improve soil physical properties. According to the World Health Organization (WHO), organic farming is a “... comprehensive system for production management which encourages and strengthens the sustainability of agro ecosystems, including an emphasis on using materials as opposed to synthetic ones".

A major component of sustainable agriculture is to sustain the productivity and improve the soil quality. Increased attention is now being paid to developing such a plant nutrition systems that maintain or enhance soil productivity through a balanced use of mineral fertilizers combined with organic sources of plant nutrients, including biological nitrogen fixation (Singh et al, 2012; Dwivedi, 2014). Agricultural production becomes imperative for establishment of the relationships between crop productivity, use of plant nutrients and soil characteristics.

Objectives of this study were: effect of low and high doses of mineral and organic fertilization on the quality of top yield and root mass of alfalfa and effect of mineral and organic fertilization on formation of quality of soil organic matter in dry condition of this region.

\section{MATERIALS AND METHODS}

The experiment was carried out in the experimental field of the Institute of Forage Crops, Pleven, Bulgaria (2000-2003) 
on leached chernozem soil subtype without irrigation. Alfalfa variety Victoria (production of the same Institute) was sown at sowing rate of $30 \mathrm{~kg} / \mathrm{ha}$. Plots size were $10 \mathrm{~m}^{2}$. The experiment was conductted using 4 replications.

Nitrogen as ammonium nitrate was applied in doses of 70 , 140 and $210 \mathrm{~kg} / \mathrm{ha}$ as mineral and organic form. Phosphorous was applied as triple super phosphate at doses to all treatments of $300 \mathrm{~kg} / \mathrm{ha}$. Potassium was applied as potassium chloride in dose of $150 \mathrm{~kg} / \mathrm{ha}$ for all treatments. Corresponding amount of nutrients were applied as very well matured cattle manure. The following scheme was used (the doses are in active ingredient): $\mathrm{N}_{0} \mathrm{P}_{300} \mathrm{~K}_{150}$ - control; $\mathrm{N}_{70} \mathrm{P}_{300} \mathrm{~K}_{150}-\mathrm{N}$ applied as mineral fertilizer; $\mathrm{N}_{140} \mathrm{P}_{300} \mathrm{~K}_{150}$ - N applied as mineral fertilizer; $\mathrm{N}_{210} \mathrm{P}_{300} \mathrm{~K}_{150}-\mathrm{N}$ applied as mineral fertilizer; $\mathrm{N}_{70} \mathrm{P}_{300} \mathrm{~K}_{150}-\mathrm{N}$ applied as manure; $\mathrm{N}_{140} \mathrm{P}_{300} \mathrm{~K}_{150}-\mathrm{N}$ applied as manure; $\mathrm{N}_{210} \mathrm{P}_{300} \mathrm{~K}_{150}-\mathrm{N}$ applied as manure. The soil and manure nutrients were determined by Page et al. (1982).

One cut for forage was obtained in the first year, forth cuts during the second and forth year, and three cuts in the third year. Dry mass yield $(\mathrm{kg} / \mathrm{ha}$ ) was calculated from fresh mass yield and $\%$ dry matter. Sustainable yield index (SYI) developed by Singh et al. (1990) was used for assessment:

SYI (Sustainable yield index $)=(\mathrm{Ym}-\mathrm{Sd}) / \mathrm{Ymax}$, where:

Ym - mean yield

Sd - standard deviation

Ymax - the maximum yield

Soils from soil profile were taken at depths $40 \mathrm{~cm}$, root mass were washed with tap water (Beck et al., 1993) and recorded for: 1) for the first year of growing: root mass density (RMD) as $\mathrm{g} / \mathrm{cm}^{3}=$ roots fresh weight $(\mathrm{g}) /$ roots volume $\left(\mathrm{cm}^{3}\right)$; root volume was measured using fresh roots of each plant by the water displacement method, using graduated cylinder (Saleh and Gritton, 1988); specific root length $(\mathrm{SRL})$ as $\mathrm{cm} / \mathrm{g}=$ root length $(\mathrm{cm}) /$ root weight $(\mathrm{g})$. 2) for the whole period of growing (four years) was done as follows: dry root mass $(\mathrm{kg} / \mathrm{ha}$ ) was calculated from fresh mass and $\%$ dry matter (dried at $\left.60{ }^{\circ} \mathrm{C}\right)$; total $\mathrm{N}(\mathrm{kg} / \mathrm{ha})$ in dry forage mass yield was calculated multiplying dry forage mass yield and $\% \mathrm{~N}$ content; total $\mathrm{N}(\mathrm{kg} / \mathrm{ha})$ in dry root mass yield was calculated multiplying dry root mass yield and \% $\mathrm{N}$ content; total $\mathrm{N}$ in dry aboveground mass $/ \mathrm{N}$ in dry root mass ratio was calculated. Plant available N (PAN) (kg/ha) was calculated according to Sullivan and Andrews (2012):

PAN (plant available nitrogen) $(\mathrm{kg} / \mathrm{ha})=$ Total $\mathrm{N}(\mathrm{kg} / \mathrm{ha}) \times 0.4$

$0.4=40 \%$ Nitrogen release (accepted estimation).
The soil used had the following agrochemical characteristics: total C, 2.8; total N, 0.23; $\mathrm{P}\left(\mathrm{P}_{2} \mathrm{O}_{5}\right), 5.3 \mathrm{mg} / 100 \mathrm{~g}$ soil; $\mathrm{K}\left(\mathrm{K}_{2} \mathrm{O}\right), 48.4 \mathrm{mg} / 100 \mathrm{~g}$ soil; $\mathrm{pH}\left(\mathrm{H}_{2} \mathrm{O}\right)$ 7.05; NH4+-N, $11.2 \mathrm{mg} \mathrm{N} / \mathrm{kg}$ soil; $\mathrm{NO}_{3}-\mathrm{N}, 8.8 \mathrm{mg} \mathrm{N} / \mathrm{kg}$ soil. The manure used had the following agrochemical characteristics on dry basis: total C, $15.0 \%$; total N, $0.72 \%$; C: N, 20.8 ; ashes, $25 \%$; $\mathrm{NH}_{4}^{+}-\mathrm{N}, 42.8 \mathrm{mg} \mathrm{N} / \mathrm{kg}$ dry manure; $\mathrm{NO}_{3}-\mathrm{N}, 541.4 \mathrm{mg}$ $\mathrm{N} / \mathrm{kg}$ dry manure; total mineral $\mathrm{N}, 584.2 \mathrm{mg} \mathrm{N} / \mathrm{kg}$ dry manure; $\mathrm{P}\left(\mathrm{P}_{2} \mathrm{O}_{5}\right), 45.3 \mathrm{mg} / 100 \mathrm{~g}$ soil dry manure; $\mathrm{K}$ $\left(\mathrm{K}_{2} \mathrm{O}\right), 78.3 \mathrm{mg} / 100 \mathrm{~g}$ dry manure; $\mathrm{pH}\left(\mathrm{H}_{2} \mathrm{O}\right)$, 6.7; humic acid, $8.55 \%$ to dry matter; fulvic acid, $0.01 \%$ to dry matter.

The concentrations of mineral nitrogen were estimated on the basis of available quantity of ammonium and nitrate nitrogen in the soil and that in the mineral fertilizer.

When applying manure we accepted for more accurate the mineralization percentages on the basis of the total nitrogen because the data on the total mineralization of nitrogen for 5 years was $46 \%$ of the initial nitrogen in the manure (www.compostingcouncil.org; www. ohioline.osu.edu; www.agriculture.purdue.edu). On that basis we applied $20.7 \mathrm{t}$ manure/ha corresponding to $70 \mathrm{~kg}$ mineral $\mathrm{N} / \mathrm{ha} ; 41.5 \mathrm{t}$ manure corresponding to $140 \mathrm{~kg}$ mineral N/ha and $62.1 \mathrm{t}$ manure corresponding to $210 \mathrm{~kg}$ mineral $\mathrm{N} / \mathrm{ha}$. Humic acids ammount $(\mathrm{kg} / \mathrm{ha}$ ) applied to the soil with the manure was as follows: with the dose of $70 \mathrm{~kg} \mathrm{~N} / \mathrm{ha}-5.985$, with the dose of $140 \mathrm{~kg} \mathrm{~N} / \mathrm{ha}-11.970$ and with the dose of $210 \mathrm{~kg} \mathrm{~N} / \mathrm{ha}-17.955$. Experimental data were statistically processed using SPSS software program.

\section{RESULTS AND DISCUSSION}

The global challenge is to meet the always increasing food demand and at the same time to protect the environmental quality. The effective management of agricultural practice is crucial to achieve this balance.

The chosen and mentioned fertilizers doses in part of Material and Methods were based because humic acids are strong biostimulants and can provoke delay if the soil is not enough supplied with nutritive elements.

Agro meteorological conditions (Table 1) in the year of swards establishing were favorable for the initial development of plants. However, the prolonged drought period occurred in May and June and reflected in relatively low dry mass yield. One cut was received only.

After the harvesting there were very hot days (end of June - beginning of July), the temperature during 12 of them was above $35^{\circ} \mathrm{C}$ (above $40^{\circ} \mathrm{C}$ were measured for two consequent days). Amount of precipitation 
(May 10.5 1/m2, June 24.4 1/m2, August - $81 / \mathrm{m} 2$ ) hinder the plant development. Root system was formed in extremely dry soil.

During the second and third year agro meteorological conditions for alfalfa development was favorable (there was a drought period in August for the second year only). Four and three cuts were obtained, respectively.

In the fourth year in the late April to mid-May a long drought was occurred, precipitations were uneven and average daily temperatures were low. Four cuts were harvested, but unfavorable conditions negatively affected dry mass yield.

Data for dry mass yield during the first year showed that fertilization increased forage productivity from 11.3 to $33.1 \%$ (Fig. 1). From the variants with mineral fertilization the highest yield was obtained for the dose of $140 \mathrm{~kg} / \mathrm{ha}$ and from manure variants, for the dose of $210 \mathrm{~kg} \mathrm{~N} / \mathrm{ha}$.

The highest dry mass yield was obtained in the second experimental year. With increasing the doses of fertilization dry mass yield increased for both fertilizers tested. Nutrients from fertilizers were used to the great extend for plant biomass formation, thus dry mass yield in the third year decreased. For mineral fertilized plants dry mass yield was significantly higher at the $\mathrm{p}<0.05$ level as compared to the control only for the lowest experimental dose, but for manure, the exceeding ranged from 10.8 to $14.6 \%$.

Dry mass yield decreased with advancing the vegetation. In the fourth year of study dry mass yield for both fertilizers was higher as compared to the control exception for high experimental dose of mineral fertilizer.

Dry mass yield after mineral fertilization varied by years much more and for the highest dose there was a tendency

\begin{tabular}{|c|c|c|c|c|c|c|c|c|}
\hline \multirow[t]{3}{*}{ Months } & \multicolumn{2}{|c|}{2000} & \multicolumn{2}{|c|}{2001} & \multicolumn{2}{|c|}{2002} & \multicolumn{2}{|c|}{2003} \\
\hline & $t$ & Rainfall & $t$ & Rainfall & $t$ & Rainfall & $\mathbf{t}$ & Rainfall \\
\hline & ${ }^{\circ} \mathrm{C}$ & $\mathrm{I} / \mathrm{m}^{2}$ & ${ }^{\circ} \mathrm{C}$ & $1 / m^{2}$ & ${ }^{\circ} \mathrm{C}$ & $\mathrm{I} / \mathrm{m}^{2}$ & ${ }^{\circ} \mathbf{C}$ & $\mathrm{I} / \mathrm{m}^{2}$ \\
\hline January & -1.1 & 54.8 & 1.4 & 23.3 & 1.4 & 18.0 & -0.1 & 53.4 \\
\hline February & 8.6 & 21.2 & 4.2 & 44.7 & 7.1 & 6.0 & -3.4 & 27.6 \\
\hline March & 12.2 & 36.1 & 11.0 & 58.3 & 9.1 & 68.0 & 4.7 & 10.2 \\
\hline April & 15.0 & 103.0 & 11.8 & 69.2 & 10.8 & 45.0 & 10.9 & 83.6 \\
\hline May & 18.6 & 10.5 & 17.6 & 50.5 & 19.5 & 32.0 & 20.5 & 74.5 \\
\hline June & 22.4 & 24.4 & 20.3 & 79.5 & 21.9 & 133.0 & 23.9 & 12.8 \\
\hline July & 25.0 & 54.3 & 24.6 & 45.3 & 23.1 & 165.0 & 23.7 & 49.7 \\
\hline August & 25.2 & 8.0 & 25.2 & 13.1 & 21.6 & 152.0 & 25.5 & 1.4 \\
\hline September & 17.5 & 65.6 & 19.0 & 64.9 & 17.1 & 70.0 & 17.7 & 67.6 \\
\hline October & 12.5 & 3.0 & 14.5 & 14.5 & 12.1 & 77.5 & 10.7 & 107.0 \\
\hline November & 8.4 & 17.4 & 5.4 & 31.5 & 7.4 & 33.1 & 7.4 & 24.8 \\
\hline December & 4.0 & 8.1 & -2.7 & 39.6 & -2.5 & 62.1 & 1.2 & 28.2 \\
\hline
\end{tabular}

for decrease. In this relation we also evaluated the sustainability of alfalfa crop under different fertilization treatments.

Sustainable yield index (SYI) showed that the alfalfa crop was more stable under organic fertilization conditions as compared with mineral ones (Fig. 2). Sustainable yield index (SYI) for the first and third year was the highest at the dose of $140 \mathrm{~kg} / \mathrm{ha}$, for the second for $70 \mathrm{~kg} / \mathrm{ha}$, and for the last year, for $210 \mathrm{~kg} / \mathrm{ha}$ applied as manure, respectively. Control plants showed the lowest sustainable yield index (SYI). The quantity of nitrogen and nutrients coming from manure did not decreased dry mass yield.

Root mass was formed in very dry conditions during the year of establishment of alfalfa and it showed small differences in the characteristics studied (Table 2). Root mass density varied in a narrow limits $(0.011-0.018)$.

Specific root length (SRL) is probably the most frequently measured morphological parameter of the roots. It is believed that it characterize the changes of roots depending on size and type of the fertilization. According to Ostonen et al. (2007) specific root length decreased significantly under fertilization. Our results showed the

Table 2: Root mass density (RMD) and specific root length (SRL) of alfalfa first year of growing

\begin{tabular}{lcc}
\hline Treatments & $\begin{array}{c}\text { RMD } \\
\text { g/cm }\end{array}$ & $\begin{array}{c}\text { SRL } \\
\mathbf{c m} / \mathbf{g}\end{array}$ \\
\hline $\mathrm{N}_{0} \mathrm{P}_{300} \mathrm{~K}_{150}$ & 0.018 & 19.68 \\
Mineral fertilizer & 0.015 & $18.93 \mathrm{a}$ \\
$\mathrm{N}_{70} \mathrm{P}_{300} \mathrm{~K}_{150}$ & 0.016 & $16.99 \mathrm{ab}$ \\
$\mathrm{N}_{140} \mathrm{P}_{300} \mathrm{~K}_{150}$ & 0.011 & $18.69 \mathrm{a}$ \\
$\mathrm{N}_{210} \mathrm{P}_{300} \mathrm{~K}_{150}$ & & \\
Manure & 0.017 & $19.70 \mathrm{ab}$ \\
$\mathrm{N}_{70} \mathrm{P}_{300} \mathrm{~K}_{150}$ & 0.015 & $24.62 \mathrm{ab}$ \\
$\mathrm{N}_{140} \mathrm{P}_{300} \mathrm{~K}_{150}$ & 0.017 & $27.21 \mathrm{ab}$ \\
$\mathrm{N}_{210} \mathrm{P}_{300} \mathrm{~K}_{150}$ & 0.009 & 1.38 \\
$\mathrm{SE}(\mathrm{P}<0.05)$ & & \\
\hline
\end{tabular}

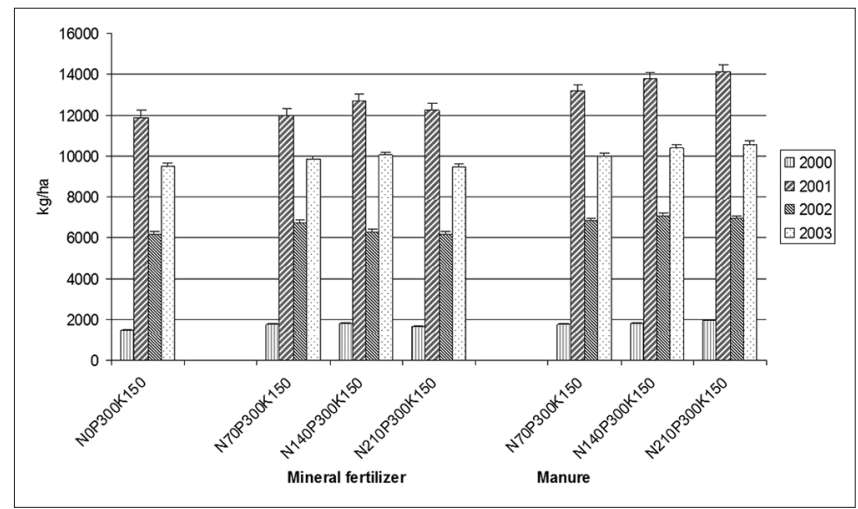

Fig 1. Dry mass yield of alfalfa. 
same. The control showed the highest specific root length because of the lower values of root mass characteristics included in the index calculation.

Campbell et al. (1997) considered 70\% of root mass of alfalfa is situated into the depth of $40 \mathrm{~cm}$. They found $4830 \mathrm{~kg} / \mathrm{ha}$ root mass of alfalfa in field trial.

Root mass of $1214 \mathrm{~kg} / \mathrm{ha}$ was recorded by Hakl et al. (2008) in the first growing year of alfalfa. Bolinder et al. (2002) measured root mass in the $15-$ to $30-\mathrm{cm}$ layer in the first year of production of alfalfa (range of 1900 to $3580 \mathrm{~kg} / \mathrm{ha}$, average of $2450 \mathrm{~kg} / \mathrm{ha}$ ) and in the second year (range of 1920 to $3660 \mathrm{~kg} / \mathrm{ha}$, average of $2800 \mathrm{~kg} / \mathrm{ha}$ ). Biederbec et al. (2005) found significant less ammount of $928-1556 \mathrm{~kg} /$ ha dry root mass accumulated in alfalfa after 5 year growing.

Dry root mass of alfalfa in our study varied from 4017 to $6027 \mathrm{~kg} / \mathrm{ha}$ (Table 3). For all variants with fertilization it was higher than the control. For mineral fertilization at the dose of $70 \mathrm{~kg} / \mathrm{ha} 4714 \mathrm{~kg} / \mathrm{ha}$ root mass was accumulated and for $140 \mathrm{~kg} / \mathrm{ha}-5196 \mathrm{~kg} / \mathrm{ha}$, which is by 17.3 and $29.4 \%$ over the control. The higher dose of mineral fertilizer had depressing effect on root mass formation and quantity of dry root mass did not significantly exceed the control at the $\mathrm{p}<0.05$ level.

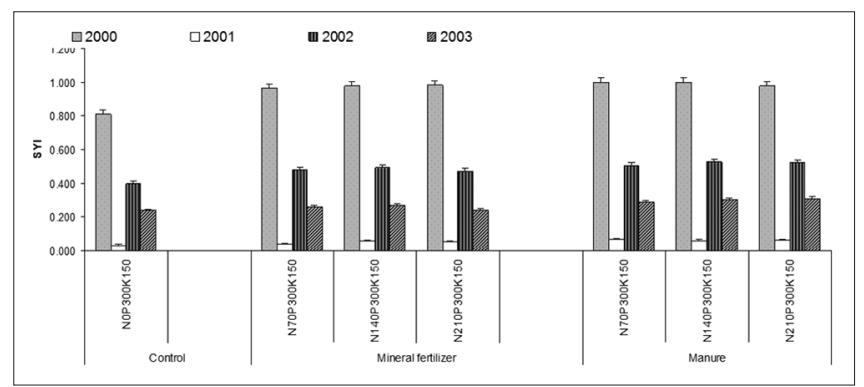

Fig 2. Sustainable yield index (SYI) for the four years of growing of alfalfa.

Table 3: Dry root mass accumulation of alfalfa after four years of growing

\begin{tabular}{|c|c|c|c|c|}
\hline \multirow[t]{2}{*}{ Treatments } & $\begin{array}{c}\text { Dry root } \\
\text { mass }\end{array}$ & $\begin{array}{c}\text { To } \\
\text { control }\end{array}$ & $\begin{array}{c}\text { To mineral } \\
\text { fertilizer }\end{array}$ & \multirow{2}{*}{$\begin{array}{l}\text { Additional to the } \\
\text { mineral fertilizer } \\
\mathrm{kg} / \mathrm{ha}\end{array}$} \\
\hline & kg/ha & \multicolumn{2}{|r|}{$\%$} & \\
\hline $\begin{array}{l}\mathrm{N}_{0} \mathrm{P}_{300} \mathrm{~K}_{150} \\
\text { Mineral fertilizer }\end{array}$ & 4017 & - & - & - \\
\hline $\mathrm{N}_{70} \mathrm{P}_{300} \mathrm{~K}_{150}$ & 4714ab & +17.3 & - & - \\
\hline $\mathrm{N}_{140} \mathrm{P}_{300} \mathrm{~K}_{150}$ & $5196 a b$ & +29.4 & - & - \\
\hline $\begin{array}{l}\mathrm{N}_{210} \mathrm{P}_{300} \mathrm{~K}_{150} \\
\text { Manure }\end{array}$ & 4179ab & +4.0 & - & - \\
\hline $\mathrm{N}_{70} \mathrm{P}_{300} \mathrm{~K}_{150}$ & $5328 b$ & +32.6 & +13.0 & 614 \\
\hline $\mathrm{N}_{140} \mathrm{P}_{300} \mathrm{~K}_{150}$ & $6027 a b$ & +50.0 & +16.0 & 831 \\
\hline $\mathrm{N}_{210} \mathrm{P}_{300} \mathrm{~K}_{150}$ & $5550 \mathrm{~b}$ & +38.2 & +32.8 & 1371 \\
\hline SE $(P<0.05)$ & 277 & & & \\
\hline
\end{tabular}

Our results are in agreement with Justes et al. (2001) who considered that alfalfa plants without nitrogen fertilizer (N0) had a significantly lower root dry mass than plants with nitrogen fertilization.

Dry root mass accumulated in alfalfa after manure application was significantly higher at the $\mathrm{p}<0.05$ level as compared to this after mineral one. Dry root mass varied between 5328 and $6027 \mathrm{~kg} / \mathrm{ha}$. There was 614 to $1371 \mathrm{~kg} / \mathrm{h}$ a root mass additional for manure treatments as compare to mineral fertilizers.

It is interesting to note that the highest doses in two types of fertilization ( $210 \mathrm{~kg} \mathrm{~N} / \mathrm{ha}$ ) formed less amount of root biomass as compared to middle dose $(140 \mathrm{~kg} \mathrm{~N} / \mathrm{ha})$.

Raza et al. (2009) studied dry root biomass of alfalfa in organically managed fields at Raasdorf, Eastern Austria for two consecutive years and found $4738 \mathrm{~kg} / \mathrm{ha}$ dry root mass in the first year, and $13103 \mathrm{~kg} / \mathrm{ha}$ dry root mass in the second year. Jones (1982) found better development of root system after manure applying due to the improved physical, chemical as well biological soil characteristics. These results correspondent to the results of specific root mass length.

The whole biomass is defined as the total sum of the plant component above and below the soil line and it is an important concept, which directly affects soil productivity (Kusvuran et al., 2014). By accumulating root mass into the soil alfalfa contributed to enchancing the soil fertility. Dubach and Russelle (1994) concluded that decaying alfalfa roots are good source of plant available nitrogen. They determined $15.36 \mathrm{~kg} / \mathrm{ha} \mathrm{N}$ was available from decaying alfalfa roots (for comparing $-3.47 \mathrm{~kg} / \mathrm{ha} \mathrm{N}$ was available from decaying birdsfoot trefoil roots), thus alfalfa roots added significant amount of nitrogen to an agro ecosystem.

Positive correlation have been found between root biomass and dry mass yield in alfalfa (Hakl et al., 2008). According to Kusvuran et al. (2014) the amount of nitrogen accumulated in alfalfa roots were observed to be much higher than that for other legumes.

The best response for $\mathrm{N}$ in root mass was found with dose of $140 \mathrm{~kg} \mathrm{~N} / \mathrm{ha}$. It was observed that the highest dose of $210 \mathrm{~kg} \mathrm{~N} / \mathrm{ha}$ in these dry condition did not stimulate formation of bigger root mass which can reduce the drought stress. It is well known that high doses of mineral nitrogen inhibit biological nitrogen fixation.

Our results are in agreement with Zhang et al. (2013) who reported $817 \mathrm{~kg} /$ ha nitrogen in root mass of alfalfa under mineral fertilization. 
It was observed higher amount of $\mathrm{N}$ in the yields in the treatments with manure both, in root and aboveground mass. With increasing the doses of manure applied, $\mathrm{N}$ in the root mass progressively incresed and reached value of $1475 \mathrm{~kg} / \mathrm{ha}$ (Table 4). Total $\mathrm{N}$ in the dry aboveground mass were smaller as compared to these in dry root mass. The tendency for higher $\mathrm{N}$ in the yield in manure treatments was stable. Also the higher values for $\mathrm{N}$ in dry root mass $/ \mathrm{N}$ in dry aboveground mass ratio were observed for treatments with manure application.

Alfalfa had a greater proportion of nitrogen stored in the roots and removing a crop still provided for the return of a substantial amount of nitrogen into the soil. Growing a pure stand of alfalfa for 4 years added a considerable amount of nitrogen to the soil.

According to Biederbec et al. (2005) the high N supply to soils increase soil organic matter and improve soil structure. The obtained results showed that $\mathrm{N}$ improve quality of organic matter, completely recovered mineralized soil $\mathrm{N}$ and maintain positive $\mathrm{N}$ balance of soils occupied with alfalfa.

Table 4: Nitrogen in dry root and aboveground mass of alfalfa after four years of growing

\begin{tabular}{lccc}
\hline Treatments & $\begin{array}{c}\mathrm{N} \text { in dry } \\
\text { root } \\
\text { mass }\end{array}$ & $\begin{array}{c}\mathrm{N} \text { in dry } \\
\text { aboveground } \\
\text { mass }\end{array}$ & $\begin{array}{c}\mathbf{N} \text { in dry root mass/ } \\
\mathbf{k} \text { in dry } \\
\text { aboveground mass } \\
\text { ratio }\end{array}$ \\
\cline { 2 - 3 } $\mathrm{N}_{0} \mathrm{P}_{300} \mathrm{~K}_{150}$ & 773 & 769 & 1.005 \\
Mineral fertilizer & & & \\
$\mathrm{N}_{70} \mathrm{P}_{300} \mathrm{~K}_{150}$ & $962 \mathrm{a}$ & $808 \mathrm{a}$ & $1.191 \mathrm{ab}$ \\
$\mathrm{N}_{140} \mathrm{P}_{300} \mathrm{~K}_{150}$ & $1077 \mathrm{ab}$ & $818 \mathrm{a}$ & $1.318 \mathrm{ab}$ \\
$\mathrm{N}_{210} \mathrm{P}_{300} \mathrm{~K}_{150}$ & $893 \mathrm{a}$ & $756 \mathrm{ab}$ & $1.180 \mathrm{ab}$ \\
$\mathrm{Manure}$ & & & \\
$\mathrm{N}_{70} \mathrm{P}_{300} \mathrm{~K}_{150}$ & $1141 \mathrm{ab}$ & $863 \mathrm{ab}$ & $1.321 \mathrm{ab}$ \\
$\mathrm{N}_{140} \mathrm{P}_{300} \mathrm{~K}_{150}$ & $1447 \mathrm{~b}$ & $905 \mathrm{~b}$ & $1.599 \mathrm{ab}$ \\
$\mathrm{N}_{210} \mathrm{P}_{300} \mathrm{~K}_{150}$ & $1475 \mathrm{~b}$ & $915 \mathrm{~b}$ & $1.612 \mathrm{ab}$ \\
$\mathrm{SE}(\mathrm{P}<0.05)$ & 101 & 23 & 0.008 \\
\hline
\end{tabular}

Table 5: Total nitrogen in dry root and aboveground mass of alfalfa after 4 year of growing

\begin{tabular}{|c|c|c|c|c|}
\hline \multirow[t]{2}{*}{ Treatments } & \multirow{2}{*}{$\begin{array}{c}\begin{array}{c}\mathrm{N} \text { in dry root } \\
\text { mass }+\mathrm{N} \text { in dry } \\
\text { aboveground mass }\end{array} \\
\mathrm{kg} / \mathrm{ha}\end{array}$} & $\begin{array}{c}\text { To } \\
\text { control }\end{array}$ & $\begin{array}{c}\text { To } \\
\text { mineral } \\
\text { fertilizer }\end{array}$ & $\begin{array}{l}\mathrm{N} \text { of dry } \\
\text { root mass } \\
\text { to total } \mathrm{N}\end{array}$ \\
\hline & & \multicolumn{3}{|c|}{$\%$} \\
\hline $\begin{array}{l}\mathrm{N}_{0} \mathrm{P}_{300} \mathrm{~K}_{150} \\
\text { Mineral } \\
\text { fertilizer }\end{array}$ & 1542 & - & - & 50.1 \\
\hline $\mathrm{N}_{70} \mathrm{P}_{300} \mathrm{~K}_{150}$ & $1770 a$ & +14.8 & - & 54.4 \\
\hline $\mathrm{N}_{140} \mathrm{P}_{300} \mathrm{~K}_{150}$ & $1894 a b$ & +22.8 & - & 56.9 \\
\hline $\begin{array}{l}\mathrm{N}_{210} \mathrm{P}_{300} \mathrm{~K}_{150} \\
\text { Manure }\end{array}$ & $1650 a$ & +7.0 & - & 54.1 \\
\hline $\mathrm{N}_{70} \mathrm{P}_{300} \mathrm{~K}_{150}$ & $2005 a b$ & +30.0 & +13.3 & 56.9 \\
\hline $\mathrm{N}_{140} \mathrm{P}_{300} \mathrm{~K}_{150}$ & 2352ab & +52.5 & +24.2 & 61.5 \\
\hline $\mathrm{N}_{210} \mathrm{P}_{300} \mathrm{~K}_{150}$ & $2390 a b$ & +55.0 & +44.8 & 61.7 \\
\hline SE $(P<0.05)$ & 124 & & & \\
\hline
\end{tabular}

The sum of total $\mathrm{N}$ in dry root mass and total $\mathrm{N}$ in dry aboveground mass in variants with mineral fertilization at the dose of $210 \mathrm{~kg} / \mathrm{ha}$ did not showed significant increase at the $\mathrm{p}<0.05$ level as compared to the control (Table 5).

The increase of total $\mathrm{N}$ in plant biomass at mineral fertilization treatments varied from $7.0 \%$ to $22.8 \%$. The highest increase was found at the dose of $140 \mathrm{~kg} \mathrm{~N} / \mathrm{ha}$. Significantly higher increase of $\mathrm{N}$ in the biomass at the $\mathrm{p}<0.05$ level can be seen at manure treatments. Increase of $\mathrm{N}$ varied from $30.0 \%$ at the lowest dose of manure to $55.0 \%$ at the highest one. Organic $\mathrm{N}$ did show inhibition effect on $\mathrm{N}$ accumulation at this highest dose. All manure treatments showed higher N (13.3-44.8\%) content in biomass as compare to mineral nitrogen treatments. Next to the improving soil properties organic fertilization demonstrated much higher yield and quality of the yield.

The results (Fig. 3) showed that plant available nitrogen of $388 \mathrm{~kg} / \mathrm{ha}$ for mineral fertilization at the dose of $70 \mathrm{~kg} / \mathrm{ha}$ and $431 \mathrm{~kg} / \mathrm{ha}$ for the dose of $140 \mathrm{~kg} / \mathrm{ha}$ were by $24.5 \%$ and $39.3 \%$ higher then control, respectively. With increasing the doses of manure plant available nitrogen increased. Plant available nitrogen from manure treated plants was higher as compared to plant available nitrogen from mineral ones. For the dose of $70 \mathrm{~kg} / \mathrm{h}$ h it was $18.6 \%$. For the dose of $140 \mathrm{~kg} / \mathrm{ha}$ it was $34.4 \%$ and for the dose of $210 \mathrm{~kg} /$ ha it was $65.2 \%$.

In addition to released $\mathrm{N}$ in soil alfalfa add a considerable amount of organic matter to the soil. Alfalfa fix atmospheric $\mathrm{N}_{2}$ and adds also humus and nutrients to the soil (Biederbec et al., 2005). Pachev (1997) found alfalfa grown for forage formed significantly high amount of humus in the soil layer 0-40 cm and improving balance of humus and increase humic acids content.

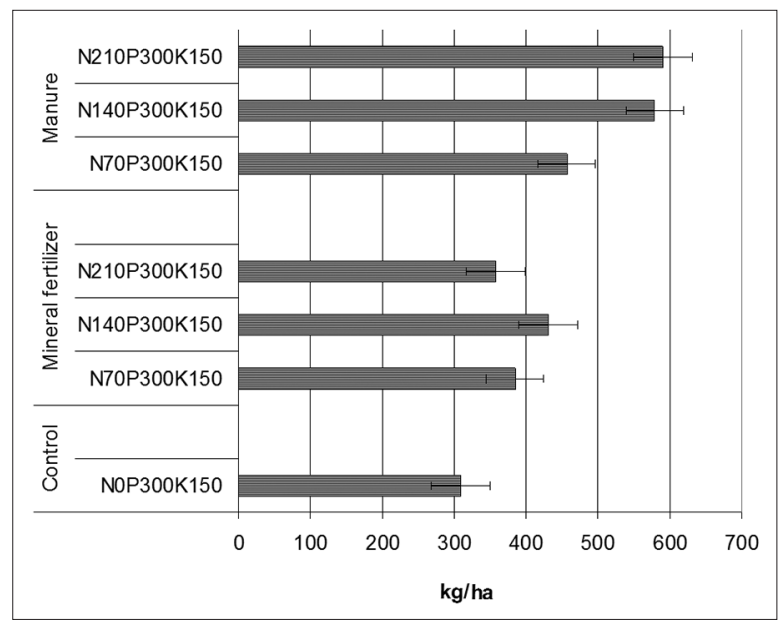

Fig 3. Plant available nitrogen (PAN). 
In our study humus content in the soil (Table 6) was increased for both type of fertilizers tested: slightly (from 5.0 to $8.0 \%$ ) for mineral fertilization and significant more (from 16.4 to $53.2 \%$ ) for manure application. In control the increase was only $2 \%$. When compare mineral and manure treatments it was observed from 10.9 to $41.9 \%$ more humus content in the manure treatments. The highest amount of humus remained into the soil after fertilization of alfalfa at the dose of $140 \mathrm{~kg} / \mathrm{ha}$.

Our results indicated that organic fertilization enhanced both, organic matter in the soil and forage yield of alfalfa. Correlation coeffiecient between dry mass yield and humus content was found to be $r=0.925$.

Kusvuran et al. (2014) consider the cultivation of alfalfa as one of the best ways to increase soil organic matter. Soils with high humus content are less likely to be subject to water and wind erosion and will maintain better level of microbial diversity and activity.

Carbon and nitrogen content are good indicators for soil quality. Plants can translocate $20-50 \%$ of total fixed carbon to their roots (Kuzyakov and Domanski, 2000). With maximizing formation of root biomass $\mathrm{C}$ inputs into the soil increased. Root biomass contains approximately $40 \%$ $\mathrm{C}$ and about $18 \%$ of the root $\mathrm{C}$ for year could be converted in humus (Kwabiah et al., 2005).

Tiwari et al. (2002) have also reported that the inclusion of manure in the fertilization schedule improved the organic carbon status and available N, P, K and S in soil, thus sustaining soil health. Soil organic matter is an important source of nutrients for plant growth that needs to be maintained for agricultural sustainability (Herencia et al., 2007). The use of organic manure enhances the content of organic carbon in the soil more than

\begin{tabular}{|c|c|c|c|c|c|c|}
\hline \multirow[t]{2}{*}{ Treatments } & \multirow{2}{*}{ Humus } & \multirow{2}{*}{$\begin{array}{l}\text { Organic } \\
\mathbf{C}\end{array}$} & \multicolumn{3}{|c|}{$\begin{array}{l}\text { Organic C, extr. with } \\
0.1 \mathrm{M} \mathrm{Na} \mathrm{P}_{2} \mathrm{O}_{7}+0.1 \mathrm{M} \\
\qquad \mathrm{NaOH}^{*}\end{array}$} & \multirow[t]{2}{*}{$\mathrm{Ch} / \mathrm{Cf}$} \\
\hline & & & Total & $\begin{array}{c}\text { in } \\
\text { humic } \\
\text { acids }\end{array}$ & $\begin{array}{c}\text { in } \\
\text { fulvic } \\
\text { acids }\end{array}$ & \\
\hline $\begin{array}{l}\mathrm{N}_{0} \mathrm{P}_{300} \mathrm{~K}_{150} \\
\text { Mineral fertilizer }\end{array}$ & 2.01 & 1.17 & 0.30 & 0.18 & 0.12 & 1.50 \\
\hline $\mathrm{N}_{70} \mathrm{P}_{300} \mathrm{~K}_{150}$ & $2.11 \mathrm{a}$ & $1.22 \mathrm{a}$ & $0.31 a$ & $0.23 a$ & $0.08 a$ & $2.88 a$ \\
\hline $\mathrm{N}_{140} \mathrm{P}_{300} \mathrm{~K}_{150}$ & $2.17 a$ & $1.26 \mathrm{a}$ & $0.38 a b$ & $0.27 a b$ & $0.11 a b$ & $2.45 a$ \\
\hline $\begin{array}{l}\mathrm{N}_{210} \mathrm{P}_{300} \mathrm{~K}_{150} \\
\text { Manure }\end{array}$ & $2.14 \mathrm{a}$ & $1.24 a$ & $0.32 a$ & $0.25 a$ & $0.07 a$ & $3.57 a b$ \\
\hline $\mathrm{N}_{70} \mathrm{P}_{300} \mathrm{~K}_{150}$ & 2.34ab & $1.36 a b$ & $0.40 a b$ & $0.31 \mathrm{ab}$ & $0.09 b$ & $3.44 a b$ \\
\hline $\mathrm{N}_{140} \mathrm{P}_{300} \mathrm{~K}_{150}$ & $3.08 a b$ & $1.79 b$ & $0.58 a b$ & $0.49 a b$ & $0.09 b$ & $5.44 a b$ \\
\hline $\mathrm{N}_{210} \mathrm{P}_{300} \mathrm{~K}_{150}$ & $2.94 a b$ & $1.71 b$ & $0.50 \mathrm{ab}$ & $0.27 a b$ & $0.23 a b$ & $1.17 a b$ \\
\hline SE $(P<0.05)$ & 0.16 & 0.09 & 0.04 & 0.03 & 0.02 & 0.54 \\
\hline
\end{tabular}

$\%$ to the soil application of the same amount of nutrients as inorganic fertilizers. A study in US (Follet, 2001) estimates that application of manure in soil would result in a sequestration at the rate of $200-500 \mathrm{~kg} \mathrm{C} /$ ha per year.

Our results indicated that fertilization increased content of organic $\mathrm{C}$ in soil depend on the doses applied (Table 6). Manure led to significantly more organic $\mathrm{C}$ and followed the tendency for humus accumulation.

Humic acid is one of the most biochemically active elements in humus. Taking into account to the biochemically active nature of humic acid and its ability to form both, soluble and insoluble complexes with various metals, minerals and organics, nutrients are mobilized in forms that the plants can accept. The biochemically active nature of humic acid works to enhance formation of root mass.

The increase of humic acids content after mineral fertilization in our study varied from 27.8 to $50.0 \%$, and after manure from 50.0 to $172.2 \%$. The highest percent of increase was with the dose of $140 \mathrm{~kg} / \mathrm{ha}$ for both, mineral and manure applications.

The results obtained strongly suggested that alfalfa grown 4 years for forage prepared the soil for the next crop in regard to quantity and quality of humus and better physical and chemical characteristic of soil fertility.

Data for the balance of nitrogen showed that leached chernozem soil has high nitrogen mineralization coefficient and could support particularly high values of biological nitrogen fixation process (Table 7). Relatively high values of nitrogen, which is returning into the soil after roots

\section{Table 7: Balance of nitrogen after mineral and manure} fertilized alfalfa grown for forage

\begin{tabular}{|c|c|c|c|c|c|c|}
\hline \multirow[t]{4}{*}{ Treatments } & $\begin{array}{l}\mathrm{N} \text { in } \\
\text { root } \\
\text { mass }\end{array}$ & $\begin{array}{c}\mathrm{N} \\
\text { exported } \\
\text { with } \\
\text { forage }\end{array}$ & $\begin{array}{l}\text { Total N } \\
\text { formed }\end{array}$ & $\begin{array}{c}\mathrm{N} \\
\text { imported } \\
\text { with } \\
\text { fertilizers }\end{array}$ & $\begin{array}{l}\mathrm{N} \text { from the } \\
\text { soil and } \\
\text { biological } \\
\text { fixation }\end{array}$ & $\begin{array}{c}\text { Return } \\
\text { of } \mathrm{N} \text { in } \\
\text { the soil } \\
\%\end{array}$ \\
\hline & & & $1+2$ & & 3-4 & $1 / 3 \times 100$ \\
\hline & 1 & 2 & 3 & 4 & 5 & 6 \\
\hline & \multicolumn{6}{|c|}{ kg N/ha } \\
\hline $\begin{array}{l}\mathrm{N}_{0} \mathrm{P}_{300} \mathrm{~K}_{150} \\
\text { Mineral } \\
\text { fertilizer }\end{array}$ & 323 & 769 & 1092 & 0.00 & 1092 & 30 \\
\hline $\mathrm{N}_{70} \mathrm{P}_{300} \mathrm{~K}_{150}$ & $323 b$ & 808 & 1131 & 70 & 1061 & $29 a$ \\
\hline $\mathrm{N}_{140} \mathrm{P}_{300} \mathrm{~K}_{150}$ & 369 & 818 & 1187 & 140 & 1047 & $31 a$ \\
\hline $\begin{array}{l}\mathrm{N}_{210} \mathrm{P}_{300} \mathrm{~K}_{150} \\
\text { Manure }\end{array}$ & 419 & 756 & 1175 & 210 & 965 & $36 a b$ \\
\hline $\mathrm{N}_{70} \mathrm{P}_{300} \mathrm{~K}_{150}$ & 566 & 863 & 1429 & 70 & 1359 & $40 \mathrm{~b}$ \\
\hline $\mathrm{N}_{140} \mathrm{P}_{300} \mathrm{~K}_{150}$ & 697 & 905 & 1602 & 140 & 1462 & $44 b$ \\
\hline $\mathrm{N}_{210} \mathrm{P}_{300} \mathrm{~K}_{150}$ & 791 & 916 & 1707 & 210 & 1497 & $46 a b$ \\
\hline SE $(P<0.05)$ & 45 & 19 & 59 & & 67 & 5 \\
\hline
\end{tabular}

*\%, coefficient of nitrogen recovering: Nitrogen in roots/nitrogen in roots and forage 
Table 8: Correlation coefficients between characteristics studied Characteristics studied $r$ Dry mass $x$ dry root mass accumulation 0.998 Dry mass xnitrogen in dry root mass 0.990 Dry mass xtable plant available nitrogen

Dry massxhumus

Dry root mass accumulation $\times$ nitrogen in dry root mass

Dry root mass accumulation $\times$ humus

decomposition, showed that soil sown with alfalfa represents an agro ecosystem, capable to recover and even to improve soil fertility in regard to nitrogen and humus content of the soil. The smaller part of recovered nitrogen in variants with mineral fertilizer showed that for this soil type with high nitrogen mineralization potential, the main measure to ensure high and stable yields should be directed to improving the water holding capacity through organic fertilization.

The predominated conception in the literature for increasing the level of soil organic matter and maintaining high and stable yields through fertilization is particularly with high doses of manure application (30-130 t/ha) (Raviv et al., 2004). Use of organic resources is a feasible approach to overcome soil fertility constraints. The applied nitrogen with organic fertilizers did not caused toxicity of the soil, as well did not depressed the symbiotically biological nitrogen fixation and also did not reduced nitrogen fixation of free-living soil nitrogen fixators mainly because of the slowly release of nitrogen and bio stimulating effect of humic acid in organic fertilizers.

The highest doses used in this study showed that mineral nitrogen from mineral fertilizer had toxic effect on alfalfa plants by inhibition of biological $\mathrm{N}_{2}$ fixation resulted in lower yield, but the nitrogen from the manure had no any toxic effect and the yield was higher in all studied doses.

Having in a mind the declining of organic matter, soil fertility and rising energy and nitrogen fertilizer costs over the past decades, the role of alfalfa as a builder of soil organic matter and conservation of agro ecosystem will likely gain more ecological and economical importance in the future for soil conservation and sustainable activity.

The high correlation coefficients (Table 8) also confirmed that all studied factors are related to development of alfalfa at dry conditions and all together determined the rate of development of alfalfa.

\section{CONCLUSIONS}

Dry mass yield of alfalfa fertilized with manure was from 9.5 to $15.9 \%$ higher as compared to dry mass yield obtained

from alfalfa fertilized with mineral fertilizer. Sustainable yield index showed the alfalfa crop was more stable under organic fertilization compared with mineral one. Alfalfa accumulated from 4017 to $6027 \mathrm{~kg} / \mathrm{ha}$ dry root mass for 4-year period of growing. There was from 614 to $1371 \mathrm{~kg} /$ ha root mass additional with manure application. The ammount of $962 \mathrm{~kg} / \mathrm{ha}$ to $1077 \mathrm{~kg} / \mathrm{h}$ a was found for nitrogen in dry root mass yield with mineral fertilization and from 1141 to $1475 \mathrm{~kg} / \mathrm{ha}$ with manure fertilization. Manure treated plants showed higher values for nitrogen in dry root mass, nitrogen in dry aboveground mass and plant available nitrogen. In addition to nitrogen alfalfa add a considerable amount of organic matter to the soil. Humic acids content after mineral fertilization was increased to $50.0 \%$ as compared to control and tree times higher with manure application. Humus content in the soil was increased by $8.0 \%$ after mineral fertilization and by $53.2 \%$ for manure applications. Humus content in the soil after manure fertilization was from 10.9 to $41.9 \%$ higher as compared to humus content after mineral one. It can be concluded that alfalfa 4-years grown for forage improve soil fertility, increase root and top biomass and prepared better soil conditions for the next crop. The decreased of organic matter content in European soils and other countries in the world, soil fertility, rising energy and nitrogen fertilizer costs over the past decades, the role of alfalfa as a builder of soil organic matter and conservation of the soil fertility will likely gain more ecological and economical importance in the future for soil conservation and sustainable agriculture.

\section{ACKNOWLEDGEMENT}

Sincere thanks are expressed to Prof. Dr. Mohammad Athar, California Department of Food and Agriculture, Sacramento, CA, USA, for the critical comments and valuable suggestions on the manuscript.

\section{Authors contributions}

$\mathrm{V}$. V. and O. K. have an equal contribution to the paper. $\mathrm{V}$. V. conducted the experiment, analyzed the results, and preparing the draft manuscript. O.K. improved the paper.

\section{REFERENCES}

Available from: https://www.cotswoldseeds.com/seed-info/lucernepractical-guide.

Available from: http://www.agriculture.purdue.edu.

Available from: http://www.compostingcouncil.org.

Available from: http://www.ohioline.osu.edu.

Beck, D. P., L. A. Materon and F. Afandi. 1993. Practical RhizobiumLegume Technology Manual, ICARDA, Aleppo, Syria.

Biederbec, V. O., H. A. Bjorge, S. A. Brandt, J. L. Henry, G. E. Hultgreen and G. A. Kielly. 2005. Soil improvements with legumes. In: Green, B. J. and V. O. Biederbeck, editors. Soils, 
Fertility and Nutrients. Canada-Saskatchewan Agreement on Soil Conservation, Saskatoon.

Bolinder, M. A., D. A. Angers, G. Bélanger, R. Michaud and M. R. Laverdière. 2002. Root biomass and shoot to root ratios of perennial forage crops in eastern Canada. Can. J. Plant Sci. 82: 731-737.

Campbell, C. A., H. H. Janzen and N. G. Juma. 1997. Case studies of soil quality in the Canadian Prairies: Long-term field experiments. In: Gregorich, E. G. and M. R. Carter, editors. Soil Quality for Crop Production. Elsevier Science Publishers, Amsterdam, p. 351-397.

Dubach, M. and M. P. Russelle. 1994. Forage legume roots and nodules and their role in nitrogen transfer. Agron. J. 86: 259-266.

Dwivedi, A. K. 2014. Impact of continuous cropping with fertilizer and manure application on soil fertility and crop productivity. CAFT on Management of Soil Health: Challenges and Opportunities. Jawaharlal Nehru Krishi Vishwa Vidyalaya, Jabalpur - 482004 (M.P.) p104-107.

Follett, R. 2001. Soil Management concepts and carbon sequestration in crop-land soils. Soil Tillage Res. 61: 77-92.

Goss, M. J., A. Tubelleh and D. Goorahoo. 2013. A review of the use of organic amendments and the risk to human health. Adv. Agron. 120: 275-379.

Hakl, J., J. Santrucek and L. Krajic. 2008. The effect of root morphology on alfalfa yield in the spring regrowth period. Grassland Sci. Europe. 13: 251-253.

Herencia, J. F., J. C. Ruiz-Porras, S. Melero, P. A. Garcia-Galavis, E. Morillo and C. Maqueda. 2007. Comparison between organic and mineral fertilization for soil fertility levels, crop macronutrient concentrations and yield. Agron. J. 99: 973-983.

Jarvis, S. C. 2005. $\mathrm{N}$ flow and $\mathrm{N}$ efficiency in legumes based systems: A system overview. In: proceedings of the $2^{\text {nd }}$ COST 852 Workshop Grado 'Sward dynamics, N-flows and Forage Utilisation in Legume-Based Systems. Pp. 187-198.

Jones F.G.W. 1982. The soil plant environment. In: Sonthey, J. F., editor. Plant Nematology. Her Majesty's Stationery Office, London.

Justes, E., P. Thiébeau, J. C. Avice, G. Lemaire, J. J. Volenec and A. Ourry. 2001. Influence of summer sowing dates, $N$ fertilization and irrigation on autumn VSP accumulation and dynamics of spring regrowth in alfalfa (Medicago sativa L.). J. Expt. Bot. 53: 111-121.

Kertikova, D. 2008. The newest achievements in lucerne breeding in Bulgaria. In: Proceedings 'Breeding 08', Novi Sad, Serbia. Pp. 509-512.

Kusvuran, A., Y. Ralice and T. Saglamtimur. 2014. Determining the biomass production capacities of certain forage grasses and legumes and their mixtures under mediterranean regional conditions. Acta Adv. Agric. Sci. 2: 13-24.

Kuzyakov, Y. and G. Domanski. 2000. Carbon input by plants into the soil review. J Plant Nutr. Soil Sci.-Z Pflanzenerna hr Bodenkd. 163: 421-431.

Kwabiah, A. B., D. Spaner and A. G. Todd. 2005. Shoot-to-root ratios and root biomass of cool-season feed crops in a boreal Podzolic soil in Newfoundland. Can. J. Soil Sci. 85: 369-376.

Ledgard, S. F. 1991. Transfer of fixed nitrogen from white clover to associated grasses in swards grazed by dairy cows estimated using ${ }^{15} \mathrm{~N}$ methods. Plant. Soil. 131: 215-223.

Luscher, A., I. Mueller-Harvey, J. F. Soussana, R. M. Rees and J. L. Peyraud. 2014. Potential of legume-based grassland - Livestock systems in Europe: A review. Grass Forage Sci. 69: 206-228.

Monteros, M. and J. H. Bouton. 2009. The future of alfalfa and forage crops. In: Proceedings, 'Western Alfalfa \& Forage Conference', Reno, Nevada, UC Cooperative Extension, Davis, CA. Pp. 1-7.
National Strategy for Sustainable Development of Agriculture in Bulgaria in the period 2014-2020. 2013. Ministry of Agriculture and Food, S. In Bulgarian.

Ostonen, I., Ü. Püttsepp, C. Biel, O. Alberton, M. R. Bakker, K. Lõhmus, H. Majdi, D. Metcalfe, A. F. M. Olsthoorn, A. Pronk, E. Vanguelova, M. Weih and I. Brunner. 2007. Specific root length as an indicator of environmental change. Plant Biosyst. - An Int. J. Dealing with all Aspects of Plant Biol. Off. J. Soc. Bot. Ital. 141(3): 426-442.

Pachev, I. 1997. Humic condition mainly soil differences in Central North of Bulgaria. Ph. D. dissertation, Agricultural Academy, Sofia, Bulgaria.

Pachev, I., Kertikov, T. and N. Georgieva. 2009. Influence of the technology of pea cultivation on nodulation and content of crop residues for improvement of soil fertility. Acta biol. lugoslavica Serija A: Zemljište I biljka. 58: 139-145.

Page, A. L., R. H. Miller and D. R. Keeney. 1982. Methods of soil analysis. Part 2. Chemical and Microbiological Properties. $2^{\text {nd }}$ ed. American Society of Agronomy. Inc., Soil Science Society of America, Inc., Madisson, Wiskonsin, USA.

Raviv, M., M. Shlomit, A. Krasnovsky and H. Ziadna. 2004. Organic matter and nitrogen conservation in manure compost for organic agriculture. Compost. Sci. Util. 12: 6-10.

Raza, A., G. Pietsch, A. Moghaddam, W. Loiskandl, M. Himmelbauer, M. R. Ardakani and J. K. Friedel. 2009. Root sampling and analysis in lucerne (Medicago sativa L.) field trial. International Symposium "Root Research and Applications" RootRAP, Vienna, Austria, Pp. 1-3.

Russelle, M. P., J. F. S. Lamb, B. R. Montgowery, D. W. Eslenheimer, R. B. S. Miller and C. P. Vance. 2001. Alfalfa rapidly remediates excess inorganic nitrogen at a fertilizer spill site. J. Environ. Q. 30: $30-36$.

Saleh, G. B. and E. T. Gritton. 1988. Genetic control of root weight, root volume and root. Pertanika. 11: 165-173.

Singh Muneshwar, R. H. Wanjare, A. Dwivedi and R. Dalal. 2012. Yield response to applied nutrients and estimates of N2 fixation in 33-years-old-soybean-wheat experiment on a vertisol. Exp. Agric. 48: 311-325.

Singh, R. P., S. K. Das, R. Bum and N. M. Reddy. 1990. Towards Sustainable Dryland Agricultural Practices. Central Research Institute Dryland Agriculture, Hyderabad, India, p. 106.

Sullivan, D. M. and N. D. Andrews. 2012. Estimating Plant-Available Nitrogen Release from Cover Crops. Pacific Northwest Extension Bulletin 636. Oregon State University, Corvallis, OR.

Tiwari, A., A. K. Dwivedi and P. R. Dikshit. 2002. Longterm influence of organic and inorganic fertilization on soil fertility and productivity of soybean-wheat system in a Vertisol. J. Indian Soc. Soil. Sci. 50: $472-475$.

Veronesi, F., E. C. Brummer and C. Huyghe. 2010. Alfalfa. In: Handbook of plant breeding: Fodder crops and amenity grasses 5 Springer, New York, USA. Pp. 395-437.

Xie H., X. Hu., C.R. Zhang, Y.F. Chen, X. Huang and X. Huang. 2013. Molecular Characterization of a stress-related Gene MsTPP in relation to somatic embryogenesis of Alfalfa. Pak. J. Bot. 45: 1285-1291.

Yuegao, H. and D. Cash. 2009. Global status and development trends of Alfalfa. In: Alfalfa Management Guide for Ningxia. United Nations Food and Agriculture Organization, Rome, Pp. 1-14.

Zhang, G., C. Zhang, Z. Yang and S. Dong. 2013. Root distribution and $\mathrm{N}$ acquisition in an Alfalfa and corn intercropping system. J. Agric. Sci. 5: 128-142. 